\title{
REALIZING SUSTAINABILITY ASPECTS BASED ON THE APPROACH OF KPIS DURING THE LIFE OF EMERGING BUILDINGS
}

\author{
Abdullah Badawy Mohammed \\ Lecturer, Architectural Engineering Department, Faculty of Engineering, Fayoum University, \\ Egypt.
}

Tel.: +20 1007595420. Postal Address: 63511

\section{E-mail: Abg00@ fayoum.edu.eg}

\begin{abstract}
The research seeks to achieve comprehensive sustainability, which takes into account the multiplicity of trends and methods to address sustainability and all its aspects. Because of the general trend toward making these aspects as indicators, the research relied on the approach of key performance indicators (KPIs) as a successful approach to promote sustainability aspects. Accordingly, the study aimed to achieve sustainability aspects based on this approach. Therefore, the study investigated this approach and its valuable role; also, collected KPIs of the three sustainability aspects, and identified the challenges of applying KPIs and their relationship with sustainability. Because of the large number of KPIs, the study proposed a methodology to deal with KPIs by ranking the three aspects and their KPIs according to priority and make decisions to accomplish the highest levels of sustainability throughout the project life. Additionally, the study evaluated the validity of this methodology through the surveys, finally applied to a type of buildings such as a hotel project, and got the results as a final guiding model to be a sustainable project.
\end{abstract}

Keywords: Key Performance Indicators (KPIs); Sustainability aspects; Economic; Social; Environmental; Hotel; Guiding model; Analytic Hierarchy Process (AHP).

\section{Introduction}

The presented views of the sustainability assessment of a building have been through the latest evolutions, feasibility studies for performance analysis, and the development of a building life cycle assessment (LCA). Besides, environmental indicators often take less significant than some of other through different tools and the case studies to appraisal sustainability ${ }^{1}$. The demand has become inevitable and obvious toward a broad array of indicators. Also, the appraisal of environmental sustainability has analyzed the different approaches and utilized types of indexes, as one critical aspect, by establishing objectives then measuring ${ }^{2}$. The importance of considering environmental and economic aspects has been highlighted by discussing the optimal use of sixteen residential buildings in Belgium from the perspective of these two aspects. Moreover, the hopeful approach of critical assessment of environmental influences has been discussed and demonstrated ${ }^{3}$. Consequently, an approach to evaluate different renovation options has been presented based on some sustainability indicators in three aspects. A methodology has been validated using three residential buildings in Sweden. The application benefit of the proposed methodology has been clarified based on the comparison between these options through the sustainability perspective ${ }^{4}$. The vast majority of the research work of green techniques have been reviewed that are applied to improve environmental sustainability throughout the building life cycles and propose the most useful ways for further research ${ }^{5,6}$. The importance of social sustainability must be taken into account in buildings, and it has been 
recognized the inadequacy of this aspect in existing assessment systems. Also, the reviewed literature has employed the approach of KPIs in renovating buildings to measure the sustainability of the built environment ${ }^{7}$. The integration of LCA and green techniques is the best way to achieve sustainable development, protect the environment, and enable decisionmaking in the construction field; hence, during the integration process that owns many current constraints have been addressed, and most negative environmental influences have been explained to occur while the manufacturing and operational stages ${ }^{8}$. A different review has been presented to know the latest evolution of techniques to achieve sustainability. A methodical approach has been used to analyze the two foremost sources: standards to techniques, literature, and guidelines; and, academic publications ${ }^{9}$. The inadequacy of a comprehensive view of social sustainability has been addressed in residential buildings when relating to modern tools and systems for assessing the sustainability of buildings. Moreover, a framework has been suggested to evaluate, examine the current and future response of techniques to social sustainability, and explore its role in using the introduced framework ${ }^{10}$; Also, the same relative to economic sustainability ${ }^{11}$.

Consequently, It should be provided a comprehensive methodology to sustainability aspects, and all their indicators, which should not be divided into parts as mentioned above during the project life by applying, measuring, evaluating, developing, and monitoring these KPIs and be accessible to all.

\section{Research Problem}

Consequently, the study revealed that designers have dealt with sustainability in the form of separate aspects, and each one takes a trend, adopts it, and does not consider others. Also, there are many trends achieving sustainability in buildings and projects; some of them focus on one aspect, such as (environmental - economic social), or the majority focus on the environmental aspect and its intervention with other aspects ${ }^{12-14}$. Or another trend through sustainability assessment systems (LEED,
BREEAM, CASBEE) ${ }^{12,15,16}$. All these trends have one purpose that is to care of human, save time, reduce effort, rationalize costs, improve performance, and preserve the environment and its resources. Consequently, these encourage to realizing and dealing with sustainability and its aspects through the approach of KPIs as variables, criteria, or benchmarks. To benefit from the advantages and positives of this approach concerning collecting and categorizing fundamental indicators for each aspect that are not limited, different, and changeable. Moreover, new KPIs may emerge over time, and project conditions may change. Due to a large number of these KPIs of three aspects, this requires a methodology or mechanism for being implemented and applied to arrange KPIs according to priority and make decisions to achieve the highest possible levels of sustainability.

\section{Research Aim and Objectives}

The research aim is to accomplish and activate the sustainability aspects by the approach of KPIs during the life of emerging buildings. The following objectives can achieve this aim:

- To depend on the approach of KPIs in how to measure and evaluate the performance of a building in terms of four categories;

- To address sustainability and its three aspects through gathering and classifying KPIs to each aspect;

- To investigate obstacles and barriers during applying KPIs to achieve sustainability, as well as the relationship between KPIs and sustainability;

- To propose a comprehensive methodology to deal with KPIs for achieving sustainability and addressing performance problems in general; and

- To evaluate the efficiency and suitability of the proposed methodology and test its validity as a tool or a mechanism to achieve KPIs of sustainability through their aspects within buildings and projects.

\section{Research Methodology}

The study adopted the inductive to describe the overall performance characteristics and basic 
requirements and needs that KPIs must meet. Then these indicators were collected and classified under four categories with which the designer deals in terms of description, units, and methods of evaluation. Then the concept of sustainability was addressed as a global trend and an approach to its three aspects (environmental - economic - social) by the approach of KPIs to assemble and classify them regarding each aspect. These KPIs were divided into variables, then into many sub-criteria for measuring and making decisions to achieve the overall sustainability.

The analytical approach was employed to study and analyze the barriers and challenges of KPIs to achieve sustainability and KPIs characteristics to overcome difficulties and obstacles. Then the relationship between the approach of KPIs and sustainability were examined to link and reconcile them by clarifying the objective of selecting and using any indicator and what KPIs provide to assist the designer in making decisions and prioritizing indicators toward sustainable design.

The deductive approach was utilized while conducting the current study and reviewing previous studies of KPIs and sustainability to conclude and deduce a methodology to achieve and activate the KPIs of the three sustainability aspects. As well as this methodology treats the performance problems in general and overcomes a problem that KPIs are too many while ranking them according to the priority of applying, activating, and implementing; then make decisions to accomplish and enhance KPIs to realize the highest possible levels of sustainability. Then the efficiency, relevance, and validity of the proposed methodology and its mechanism were evaluated by questionnaires and interviews with specialists to develop and be in its final form.

The applied approach was adopted to practically apply the proposed methodology through an example of a hotel building. Moreover, focusing on the first stage that deals with all KPIs of the three sustainability aspects in terms of ranking priorities and making decisions by the AHP tool as a final guiding model to be a basis to accomplish a sustainable hotel project.

\section{The Approach of Key Performance Indicators (KPIs)}

"Performance of a building" was defined as the behavior of a product or a service in use ${ }^{17,18}$. It can also be used to indicate the attributes of physical or subjective performance or indicators to a building as a combination of its components. It correlates with the capacity of a building to contribute to achieving or performing the functions of its occupants ${ }^{19-22}$. Traditionally, the expression "building performance" was used in the context of noise control, thermal efficiency, safety, and indoor air quality ${ }^{23,24}$. These "microlevel" criteria are essential in realizing how well a building satisfies the occupants or functionality requirements. Generally, to appraise how a building is a well-behaving through the life cycle, a more comprehensive approach is demanded through which the total building performance plays a significant role by some indicators ${ }^{25,26}$. Usually, the obtained value from the mixes of various quantifiable variables illustrates an indicator ${ }^{27,28}$. The function of a variable while representing as a sign is to send a complicated message from several possible sources in a useful and easy way ${ }^{29}$. Thus, the first objectives of the variables would be considered as simplifying and continuing for quantitative estimation ${ }^{1,30}$. KPIs are like any classification of a benchmark to measure the performance of systems or processes within a project through quantitative ways ${ }^{31}$. The purpose of data collection and estimation of KPIs is to measure, evaluate the service performance of a building, and analyze the effectiveness and efficiency of the measures were taken to improve the planning and service processes within this building ${ }^{32-34}$. Therefore, these KPIs always demand to fulfill some fundamental necessities and desires 6,28 :

1. The experimental and operational goals: KPIs should reflect the overall project's purposes. Consequently, in the service context, KPIs must quantitatively measure the extent of achievement and development of customers' desires, needs, costs, and effort; 
2. Accuracy: Describing and assessing KPIs should not neglect any area of argument or error;

3. Control: KPIs should be logic for smart decisions and variables that can be controlled by services management based on fit decisions. Therefore, KPIs must be realized by external variables for planning the performance and processes of service delivery;

4. Measurement: KPIs must be clearly defined and quantitatively measurable without excessive costs. Therefore, the required information must be available or accessible without hard investigation or surveys; and

5. Comprehensive: stakeholders can use KPIs throughout different stages of a building life cycle.

A comprehensive list of indicators, which has been collected and developed by previous studies 7,19,25,31-33,35,36. Related studies have classified KPIs under seven categories are precisely the same as the four categories include the same number of KPIs ${ }^{7}$. Consequently, this study follows the classification of four categories to identify the indicator type, its description, and measures "Units" to apply during different circumstances ${ }^{32}$. Those KPIs that aren't quantifiable or depend on moral judgments and opinions or self-estimation classify as survey-based ${ }^{18,31}$. Thirty-six major indicators were identified by previous studies to represent all KPIs. Moreover, these categorized KPIs were deduced by experts and specialists through the surveys were conducted on the eleven different building ${ }^{37,38}$.

\subsection{Physical indicators}

The appropriateness (what the required efficiency the building supports to achieve functions), the quality of space (environmental, spatial, and psychological themes), accessibility, and resource depletion as in Table 1.

\begin{tabular}{|c|c|c|}
\hline Indicators & Description & Units \\
\hline $\begin{array}{l}\text { A physical building state } \\
\text { (quantitative): Building } \\
\text { Performance Index (BPI). }\end{array}$ & $\begin{array}{l}\text { Indicates the physical and functional } \\
\text { conditions of a building (components, } \\
\text { systems, and processes). }\end{array}$ & $\begin{array}{l}\text { It is measured such as a } \\
\text { point scale. }\end{array}$ \\
\hline $\begin{array}{l}\text { A physical building state } \\
\text { (qualitative): maintenance- } \\
\text { physical state- sanitary- } \\
\text { plumbing- mechanical } \\
\text { services -lighting- electric. }\end{array}$ & $\begin{array}{l}\text { Includes maintenance in terms of routine } \\
\text { repairs in the building; sanitary, plumbing } \\
\text { and storm-water systems; mechanical } \\
\text { systems; and, lighting and electrical } \\
\text { systems. }\end{array}$ & $\begin{array}{l}\text { It is estimated on a scale } \\
\text { (good, fair, weak, and } \\
\text { unsatisfactory) } \\
\text { regarding the evaluation } \\
\text { to the state. }\end{array}$ \\
\hline Property and real estate. & $\begin{array}{l}\text { Includes the area of the property and } \\
\text { presents a valuation of owning VS renting } \\
\text { area to find out the part is owned and } \\
\text { rented. }\end{array}$ & $\begin{array}{l}\text { The area in sq. Ft. A } \\
\text { fraction of leased or } \\
\text { owned area in } \% \text { of total } \\
\text { real estate. }\end{array}$ \\
\hline Waste. & $\begin{array}{l}\text { Entire generated waste to waste of landfill, } \\
\text { disposal; also, waste disposal cost, } \\
\text { hazardous waste, and the recycled amount. }\end{array}$ & $\begin{array}{l}\text { Volume per time, mass } \\
\text { per month. Reused or } \\
\text { recycled waste: Cost: } \\
\text { \$US per volume. }\end{array}$ \\
\hline Safety and health. & $\begin{array}{l}\text { Includes a valuation to the health and safety } \\
\text { state of employees, and the project's } \\
\text { complying with applied codes linked to the } \\
\text { safety and health of occupants. }\end{array}$ & $\begin{array}{l}\text { Employees' no. of } \\
\text { accidents per year, lost } \\
\text { work hours, and } \\
\text { workers' compensation } \\
\text { claims. }\end{array}$ \\
\hline $\begin{array}{l}\text { Indoor environmental } \\
\text { quality (IEQ). }\end{array}$ & $\begin{array}{l}\text { Measured in terms of light, indoor } \\
\text { pollutants, noise, thermal comfort, and } \\
\text { ventilation; thermal comfort: air } \\
\text { temperature, humidity, air speed, and mean } \\
\text { radiant temperature; Internal air quality: }\end{array}$ & $\begin{array}{l}\text { Each parameter is } \\
\text { measured in its } \\
\text { particular units of } \\
\text { measurement. }\end{array}$ \\
\hline
\end{tabular}




\begin{tabular}{|l|l|l|}
\hline & $\begin{array}{l}\text { distribution of fresh air, comprehensive } \\
\text { pollution (vapors, smoke, gases, dust); and } \\
\text { daylight. }\end{array}$ & \\
\hline $\begin{array}{l}\text { Accessibility for } \\
\text { handicapped. }\end{array}$ & $\begin{array}{l}\text { Provision for disabled and preparedness of } \\
\text { building to accommodate individual needs. }\end{array}$ & $\begin{array}{l}\text { Level of accessibility of } \\
\text { individuals. }\end{array}$ \\
\hline $\begin{array}{l}\text { Resource energy } \\
\text { consumption: use, net, } \\
\text { annual energy } \\
\text { consumption, natural gas, } \\
\text { and electric. }\end{array}$ & $\begin{array}{l}\text { Energy consumed in ventilation, heating, } \\
\text { and air conditioning, lighting, and other } \\
\text { energy use. It does not include processing, } \\
\text { energy consumed in manufacturing or } \\
\text { commercial activities. }\end{array}$ & $\begin{array}{l}\text { KWh, Btu or Joules; } \\
\text { kWh; kW per sq. Ft. or } \\
\text { kVA per sq. Ft. }\end{array}$ \\
\hline $\begin{array}{l}\text { Resource consumption- } \\
\text { water. }\end{array}$ & $\begin{array}{l}\text { Used water for a building; also, water } \\
\text { consumption relative to reuse, treat and } \\
\text { recycle. }\end{array}$ & $\begin{array}{l}\text { Volume per month or } \\
\text { volume per product. }\end{array}$ \\
\hline $\begin{array}{l}\text { Resource consumption - } \\
\text { materials: material } \\
\text { consumption. }\end{array}$ & $\begin{array}{l}\text { The quantity of total material: used in the } \\
\text { operation process and production, and } \\
\text { consumption VS waste, reused and } \\
\text { recycled. }\end{array}$ & $\begin{array}{l}\text { Cubic feet, tons, or any } \\
\text { appropriate unit of } \\
\text { weight. }\end{array}$ \\
\hline Security. & $\begin{array}{l}\text { It describes the security state and the } \\
\text { effectiveness of security measures. }\end{array}$ & $\begin{array}{l}\text { No. of security } \\
\text { incidents per year. }\end{array}$ \\
\hline Site and location. & $\begin{array}{l}\text { Characteristics of the site of a building in } \\
\text { terms of size, location, sound, safety, } \\
\text { accessibility, topography, preservation, and } \\
\text { development. }\end{array}$ & $\begin{array}{l}\text { Points in size or length } \\
\text { to width ratio. }\end{array}$ \\
\hline
\end{tabular}

\subsection{Financial indicators}

These are related to cost during the life of a to make decisions within different building. These provide an immediate appraisal administrative levels as in Table 2.

\begin{tabular}{|c|c|c|}
\hline Indicators & Description & Units \\
\hline $\begin{array}{l}\text { Operating } \\
\text { cost. }\end{array}$ & $\begin{array}{l}\text { Total costs linked to management, such as insurance, } \\
\text { energy, air controlling, ventilation, fire protection, } \\
\text { security, cleaning, maintenance, and other payments. }\end{array}$ & \multirow[t]{2}{*}{$\begin{array}{l}\text { Money per: Unit area; } \\
\text { Person; or Product. }\end{array}$} \\
\hline $\begin{array}{l}\text { Occupancy } \\
\text { cost. }\end{array}$ & $\begin{array}{l}\text { The linked costs with a building are from beginning } \\
\text { occupying to disposal. It includes property taxes, } \\
\text { insurance concerning the building and its elements, } \\
\text { depreciation, and repayment cost. }\end{array}$ & \\
\hline Capital cost. & $\begin{array}{l}\text { All costs required for buying and extend building assets, } \\
\text { procure tools, and to operate a building. }\end{array}$ & Money per employee. \\
\hline Utility cost. & $\begin{array}{l}\text { The monthly or annual cost of benefits includes } \\
\text { electricity, fuel oil, gas, steam, water, sewage, etc. }\end{array}$ & \multirow[t]{4}{*}{ Money per unit area. } \\
\hline $\begin{array}{l}\text { Building } \\
\text { maintenance } \\
\text { costs. }\end{array}$ & $\begin{array}{l}\text { Costs for work (at house or public) and materials } \\
\text { required for building monitoring, repairs, inspection, } \\
\text { maintenance, and response to services. }\end{array}$ & \\
\hline $\begin{array}{l}\text { Ground } \\
\text { keeping Costs. }\end{array}$ & $\begin{array}{l}\text { Work costs (at house or public) and materials required } \\
\text { for landscaping, storm-water management, and parking } \\
\text { or garage maintenance. }\end{array}$ & \\
\hline $\begin{array}{l}\text { Guarding } \\
\text { Costs. }\end{array}$ & $\begin{array}{l}\text { Costs for work, personnel, supplies, and equipment used } \\
\text { for providing guarding services. }\end{array}$ & \\
\hline
\end{tabular}




\begin{tabular}{|c|c|c|}
\hline $\begin{array}{l}\text { Current } \\
\text { Replacement } \\
\text { Value (CRV). }\end{array}$ & $\begin{array}{l}\text { An estimated cost of renovating a building to its original } \\
\text { state and function. It includes the costs of materials, } \\
\text { labor, tools, architectural and engineering fees, } \\
\text { construction management, and other contingencies. }\end{array}$ & Money. \\
\hline $\begin{array}{l}\text { Deferred } \\
\text { maintenance } \\
\text { and deferred } \\
\text { maintenance } \\
\text { backlog. }\end{array}$ & $\begin{array}{l}\text { Property maintenance costs, facilities, and equipment } \\
\text { are suspended from the budget cycle of a building } \\
\text { operation owing to financial restrictions. It is measured } \\
\text { by surveys to evaluate the state of the actual property } \\
\text { and tools, also by defining the number of required funds } \\
\text { to refurbish back to a state of "as an original state." }\end{array}$ & \\
\hline $\begin{array}{l}\text { Capital } \\
\text { renewal. }\end{array}$ & $\begin{array}{l}\text { The required budget to perform primary restorations in a } \\
\text { building, its systems, subsystems, and components. }\end{array}$ & \\
\hline $\begin{array}{l}\text { Maintenance } \\
\text { Efficiency } \\
\text { Indicators } \\
\text { (MEI). }\end{array}$ & $\begin{array}{l}\text { Shows the efficiency with which maintenance activities } \\
\text { are implemented. }\end{array}$ & $\begin{array}{l}\text { MEI values can be divided } \\
\text { into three sorts: low, } \\
\text { moderate, and high (the } \\
\text { real investment within } \\
\text { maintenance compared to } \\
\text { the real performance of a } \\
\text { building). }\end{array}$ \\
\hline $\begin{array}{l}\text { Building } \\
\text { condition } \\
\text { index } \\
\text { (FCI). }\end{array}$ & $\begin{array}{l}\text { Showed by the ratio between the total cost of shortages } \\
\text { to the CRV, or by the ratio between the costs of deferred } \\
\text { maintenance to the CRV. }\end{array}$ & Percentage of CRV. \\
\hline $\begin{array}{l}\text { Movement } \\
\text { costs. }\end{array}$ & $\begin{array}{l}\text { Shows the process of moving a group of employees and } \\
\text { equipment within a period (per month or year). }\end{array}$ & $\begin{array}{l}\text { The percentage of the total } \\
\text { average of employees at a } \\
\text { specific time or money. }\end{array}$ \\
\hline
\end{tabular}

\subsection{Functional indicators}

These are the evaluation aspects related to the organization or profession missions, space, employees, and other support aspects; Moreover, aspects as building spaces, adequacy, and occupants in terms of productivity and show

better contribute of these aspects to organizational purposes. Consequently, they will reveal the state of occupants' satisfaction as in Table 3.

\begin{tabular}{|c|c|c|}
\hline \multicolumn{3}{|c|}{ Table 3. Functional indicators $7,19,32,37$. } \\
\hline Indicators & Description & Units \\
\hline Productivity. & $\begin{array}{l}\text { It measures occupant turnover rate; } \\
\text { absenteeism; or, occupant satisfaction and self- } \\
\text { rated. }\end{array}$ & $\begin{array}{l}\text { The volume of achievements } \\
\text { per year; absentees per year; } \\
\text { or survey. }\end{array}$ \\
\hline Parking & Availability of parking spaces & No. of spaces per person. \\
\hline $\begin{array}{l}\text { Occupant's } \\
\text { turnover rate. }\end{array}$ & $\begin{array}{l}\text { It is the ratio of No. of occupants turned over in } \\
\text { a period to the total average number in that } \\
\text { period. }\end{array}$ & $\begin{array}{l}\text { Ratio (No. of occupants } \\
\text { (before) to the total average } \\
\text { No. of occupants in a given } \\
\text { period (after)). }\end{array}$ \\
\hline $\begin{array}{l}\text { Mission } \\
\text { Dependency Index } \\
(\mathrm{MDI}) \text { and vision. }\end{array}$ & $\begin{array}{l}\text { A building preparation to fulfill its mission. MDI } \\
\text { indicates the priority of mission. }\end{array}$ & By using a point scale. \\
\hline $\begin{array}{l}\text { Building occupant } \\
\text { satisfaction with } \\
\text { products or } \\
\text { services. }\end{array}$ & $\begin{array}{l}\text { Measures the extent to provide the quality } \\
\text { within products and services to clients The } \\
\text { efficiency of their delivery in time, and total } \\
\text { client satisfaction with the building, its } \\
\text { elements, and services. }\end{array}$ & Survey-based data. \\
\hline
\end{tabular}




\begin{tabular}{|l|l|l|}
\hline $\begin{array}{l}\text { Adequacy of } \\
\text { space. }\end{array}$ & $\begin{array}{l}\text { Suitability of space for the functioning of the } \\
\text { building. Sufficiency of space for various } \\
\text { building operations, maintenance, and other } \\
\text { support systems. }\end{array}$ & \\
\hline $\begin{array}{l}\text { The learning } \\
\text { environment and } \\
\text { the suitability } \\
\text { educational and } \\
\text { functional. }\end{array}$ & $\begin{array}{l}\text { The suitability of a building to achieve its } \\
\text { functions about spatial, functional, and } \\
\text { psychological aspects. }\end{array}$ & \\
\hline $\begin{array}{l}\text { Community } \\
\text { satisfaction and } \\
\text { participation. }\end{array}$ & $\begin{array}{l}\text { Community involvement, interaction, } \\
\text { favorability, and satisfaction. }\end{array}$ & \\
\hline Appearance. & $\begin{array}{l}\text { Exterior and interior visual qualities, agreement } \\
\text { with surroundings, scale, and the ratio of spaces, } \\
\text { and visual stimulation. }\end{array}$ & \\
\hline Space utilization. & $\begin{array}{l}\text { Measures over-used and under-used spaces, the } \\
\text { suitability of space, and proper space } \\
\text { management. }\end{array}$ & \\
\hline
\end{tabular}

\subsection{Survey-based indicators}

These are managed by studying occupants to be measured. Surveys always depend on a questionnaire or an interview through the study type. Occupants of a building are permanent or temporary such as clients or visitors, and stakeholders if the study requires; are useful to measure the environmental and psychological aspects the highest priority is granted based on self-estimation and opinions as in Table 4.

\begin{tabular}{|l|l|l|}
\hline \multicolumn{2}{|l|}{ Table 4. Survey-based indicators ${ }^{19,31,32,37}$. } & Units \\
\hline Indicators & Description & Surveys. \\
\hline $\begin{array}{l}\text { Building occupants' satisfaction with } \\
\text { products or services. }\end{array}$ & Table 3. & \\
\hline $\begin{array}{l}\text { Community satisfaction and } \\
\text { participation. }\end{array}$ & $\begin{array}{l}\text { Community engagement, interaction, and } \\
\text { favorability, and satisfaction among its individuals. }\end{array}$ & \\
\hline $\begin{array}{l}\text { The learning environment, } \\
\text { educational suitability, and } \\
\text { appropriateness of the building to its } \\
\text { function. }\end{array}$ & Table 3. & \\
\hline Appearance. & Table 3. & \\
\hline
\end{tabular}

\section{The Concept of Sustainability}

Literature summary refers to an increasing interest in research into the built environment and sustainability of existing and emerging buildings. It also shows that sustainability is a global dilemma that requires a universal solution. There is an urgent need to develop buildings to able to appraise the sustainability of their components using international standards (economy, society, and environment) ${ }^{34,39}$. Increasing understanding of the severe effects of conventional construction practices promotes sustainable development thought. Inside sustainable development, green buildings are that have been developed with a distinct emphasis on the environment; while sustainable buildings are green buildings attempt to balance social, economic, and environmental aspects ${ }^{11}$. Therefore, dividing sustainability within these three aspects helps to accomplish it; moreover, any sustainability aspect must be sub-divided into indicators to efficiently appraisal ${ }^{1}$. Then, each indicator is divided into variables should be divided into many sub-criteria. Three principal purposes of these indicators, variables, or sub- 
criteria are to quantitative measurement; exchange of views; and, collect, simplify, and report data for making decisions throughout all project life phases ${ }^{11,30}$.

\subsection{Environmental Sustainability}

The environmental problems commonly share concerns that include reducing the use of nonrenewable materials, and water, also emissions, pollutants, and wastes. The following aims are in many sustainability evaluation methods: reduction of energy consumption, the benefit from site potentials, protect and conserve of water resources, usage of environmentally friendly materials and products, health and comfortable indoor climate, and enhance of operation and maintenance practice ${ }^{1,30}$. The world has increasingly worried about not activating these aims. Moreover, indoor environmental quality (IEQ) besides other building indicators; each of these indicators is associated with environmentally intense human activities such as burning fossil fuels, deforestation, and land-use change; all produce harmful emissions adversely influence the environment as in Table $\mathbf{5}^{8,10,40}$.

Table 5. Environmental sustainability indicators, their variables, and sub-criteria within buildings or projects $1,5,23,41,42$.

\begin{tabular}{|c|c|c|}
\hline Indicators & Variables & Sub-criteria \\
\hline \multirow{6}{*}{$\begin{array}{l}\text { Climatic } \\
\text { quality. }\end{array}$} & \multirow[t]{5}{*}{ Indoor air quality. } & Air suspension of solid particles. \\
\hline & & Carbon (monoxide-dioxide). \\
\hline & & Formaldehyde. \\
\hline & & Ozone. \\
\hline & & Organic volatile compounds. \\
\hline & Climatic change. & Global heating potential. \\
\hline \multirow{7}{*}{$\begin{array}{l}\text { Environmental } \\
\text { comfort. }\end{array}$} & \multirow[t]{2}{*}{ Hydrothermal comfort. } & Relative humidity. \\
\hline & & Winter and Summer thermal performance. \\
\hline & \multirow[t]{2}{*}{ Visual comfort. } & Natural lighting use. \\
\hline & & Illumination. \\
\hline & \multirow[t]{3}{*}{ Acoustic comfort. } & Airborne sound insulation. \\
\hline & & Reverberation time. \\
\hline & & Impact sound insulation. \\
\hline \multirow{7}{*}{\multicolumn{2}{|c|}{ Emissions and Radiations. }} & Destruction of the stratospheric ozone layer. \\
\hline & & Eutrophication potential. \\
\hline & & Formation of the ground. \\
\hline & & Ozone level. \\
\hline & & Acidification potential. \\
\hline & & Inert waste for disposal. \\
\hline & & Hazardous waste for disposal. \\
\hline \multirow[t]{5}{*}{ LCA. } & \multirow[t]{3}{*}{ Resources depletion. } & Land use. \\
\hline & & Resources depletion of Materials. \\
\hline & & Potential for fossil fuel depletion. \\
\hline & \multirow[t]{2}{*}{ Water efficiency. } & Drinking water use. \\
\hline & & Rainwater use. \\
\hline
\end{tabular}




\subsection{Social Sustainability}

Human needs have different priorities; for instance, with the issue of illiteracy, poverty inequity, and health, it can be discussed that sustainable development in developing peoples works to concentrate on socioeconomic matters rather than the environment ${ }^{11,43}$. With a focus on the social sustainability development within the building sector to be reasonably possible and suite the economic and ecological needs that adapt to the quality of occupants' needs, and it has various requirements of users' comfort to fulfill their desires ${ }^{4,44}$. Moreover, the quality of life of the population also depends on some variables based on the region, including the location of a building and its near from community services and transport ${ }^{10}$. Positive effects on the environment, public health, increasing users' productivity, increasing building, organizing marketability, and advancing toward a sustainable society is the concrete results of designing green buildings
9,10,44. Besides, all activities are mainly influenced by the building design that has the ecological- social aspects as a place of social relationships, a symbolic sense of the social situation, privacy, and familiarity by which a user identifies the essential urban presence ${ }^{9,43}$. Social sustainability is an important supplier to the Life Cycle Sustainability Assessment (LCSA) of buildings. The following conceptual equation of LCSA framework has formed ${ }^{43,45}$ : LCSA $=$ LCC + LCA + SLCA. (LCC (LifeCycle Cost), LCA (Life-Cycle Assessment), and SLCA (Social Life-Cycle Assessment)).

There are some advances in sustainability assessment instruments have begun to consider social sustainability indicators through Total Quality Assessment (TQA) for most aspects, indicators, and more relative attention to social indicators than other evaluation tools ${ }^{4,10}$. These KPIs of social sustainability, which were collected from previous studies, then classified, as shown in Table 6.

\begin{tabular}{|c|c|c|c|}
\hline Indicators & Variables & \multicolumn{2}{|c|}{ Sub-criteria } \\
\hline \multirow{10}{*}{$\begin{array}{l}\text { Functional, } \\
\text { aesthetic \& } \\
\text { innovative } \\
\text { design } \\
\text { approach. }\end{array}$} & \multirow{4}{*}{$\begin{array}{l}\text { Usability, functionality \& } \\
\text { aesthetic aspects. }\end{array}$} & \multicolumn{2}{|c|}{ Level of compliance with customer requirements. } \\
\hline & & \multicolumn{2}{|c|}{ The project stakeholders' view about usability. } \\
\hline & & \multicolumn{2}{|c|}{ The vision of stakeholders in a project about functionality. } \\
\hline & & \multicolumn{2}{|c|}{ The opinions of stakeholders about the aesthetic aspects. } \\
\hline & \multirow{3}{*}{$\begin{array}{l}\text { Architectural } \\
\text { considerations, the } \\
\text { integration of cultural } \\
\text { heritage and the level of } \\
\text { harmony with the values of } \\
\text { local heritage. }\end{array}$} & \multicolumn{2}{|c|}{$\begin{array}{l}\text { Expert opinions if the building is a world heritage or a } \\
\text { nearby world heritage. }\end{array}$} \\
\hline & & \multicolumn{2}{|c|}{ Personal opinions of stakeholders. } \\
\hline & & \multicolumn{2}{|c|}{ Society satisfaction from the cultural value of a building. } \\
\hline & \multirow{3}{*}{$\begin{array}{l}\text { Innovation \& design } \\
\text { process. }\end{array}$} & \multicolumn{2}{|c|}{ Level of commitment with available and affordable } \\
\hline & & \multicolumn{2}{|c|}{ Future-proof of the building determined by experts. } \\
\hline & & \multicolumn{2}{|c|}{ Personal opinions from a design team. } \\
\hline \multirow{7}{*}{$\begin{array}{l}\text { User comfort } \\
\text { and safety. }\end{array}$} & \multirow{5}{*}{$\begin{array}{l}\text { Indoor environmental } \\
\text { quality. }\end{array}$} & \multicolumn{2}{|c|}{ Availability of daylight illumination. } \\
\hline & & \multicolumn{2}{|c|}{$\begin{array}{l}\text { The number of times to change the air during an hour on } \\
\text { the inside. }\end{array}$} \\
\hline & & \multicolumn{2}{|c|}{ The production rate of airborne pollutants. } \\
\hline & & \multirow{2}{*}{$\begin{array}{l}\text { Personal } \\
\text { opinions of }\end{array}$} & Project stakeholders. \\
\hline & & & Construction Consultants. \\
\hline & \multirow[t]{2}{*}{ Health and well-being. } & \multicolumn{2}{|c|}{ Health care index. } \\
\hline & & \multicolumn{2}{|c|}{ Pollution index. } \\
\hline
\end{tabular}




\begin{tabular}{|c|c|c|}
\hline & \multirow{2}{*}{$\begin{array}{l}\text { Personal } \\
\text { opinions of }\end{array}$} & Project stakeholders. \\
\hline & & Construction Consultants. \\
\hline \multirow[t]{4}{*}{ Safety. } & \multicolumn{2}{|c|}{ Level of compliance with safety standards. } \\
\hline & \multicolumn{2}{|l|}{ Safety index. } \\
\hline & \multirow{2}{*}{$\begin{array}{l}\text { Personal } \\
\text { opinions of }\end{array}$} & Project stakeholders. \\
\hline & & Construction Consultants. \\
\hline \multirow[t]{3}{*}{ Open space availability. } & \multirow{3}{*}{$\begin{array}{l}\text { Available } \\
\text { open space }\end{array}$} & For seating. \\
\hline & & For ventilation and daylight. \\
\hline & & Per occupant. \\
\hline \multirow[t]{4}{*}{ No. of facility users. } & \multirow{2}{*}{$\begin{array}{l}\text { No. } \\
\text { Inhabitable } \\
\text { spaces of }\end{array}$} & Service personnel. \\
\hline & & A building's occupants. \\
\hline & \multirow{2}{*}{$\begin{array}{l}\text { Max. No. of } \\
\text { users }\end{array}$} & (Service staff) per inhabitable space. \\
\hline & & $\begin{array}{l}\text { (The building occupants) per inhabitable } \\
\text { space. }\end{array}$ \\
\hline \multirow[t]{6}{*}{ Accessibility. } & \multicolumn{2}{|c|}{ Accessibility for a disabled (if necessary). } \\
\hline & \multicolumn{2}{|c|}{ Access to the clinician and hospital. } \\
\hline & \multicolumn{2}{|c|}{ Access to services. } \\
\hline & \multicolumn{2}{|c|}{ Distance from the city center (a city). } \\
\hline & \multicolumn{2}{|c|}{ Level of compliance with customer's requirements. } \\
\hline & \multicolumn{2}{|c|}{ Traffic indicator (a city). } \\
\hline \multirow[t]{3}{*}{ Community amenities. } & \multicolumn{2}{|c|}{ Stakeholders' view on amenities. } \\
\hline & \multicolumn{2}{|c|}{ Stakeholders' satisfaction. } \\
\hline & \multicolumn{2}{|c|}{ Life quality index. } \\
\hline
\end{tabular}

\subsection{Economic Sustainability}

The concept of economic sustainability within buildings appears somewhat simple, while the appraisal is a complicated process. Moreover, when a matter is about enhancing the economic performance of buildings; it must be controlled with several variables to achieve the intended level of performance ${ }^{11}$. LCC is a significant indicator of the economic performance of buildings and projects. Hence, LCC is always used theoretically and practically for aiding the process of decision-making to choose the best alternatives ${ }^{4,11}$. Moreover, value studies are checklist points during the project-beginning phase, and life-cycle cost analysis (LCCA) is a variable of a checklist of the design phase. All costs correlated to the ownership, acquisition, as well as the demolition of a building system ${ }^{11,32}$. Not only in the form of initial costs and LCC or LCA $^{30}$. As shown in Table 7, these important indicators and variables have an immense role to play in the economic appraisal of a building are often ignored; it is necessary to confirm this role before including values of these KPIs within buildings or their framework ${ }^{2,46}$. For instance, the many types of research on economic sustainability appraisal of residential projects adopt LCC as a single standard ${ }^{1,11}$. 


\begin{tabular}{|c|c|c|}
\hline Indicators & Variables & Sub-criteria \\
\hline \multirow[t]{2}{*}{ LCC values. } & Capital cost. & $\begin{array}{l}\text { All costs required for buying and extend building } \\
\text { assets, procure tools, and to begin operating a } \\
\text { building or a project. }\end{array}$ \\
\hline & Life cycle cost. & $\begin{array}{l}\text { Operation, occupancy, utility, maintenance, and } \\
\text { guarding Costs. }\end{array}$ \\
\hline \multirow{15}{*}{$\begin{array}{l}\text { Affordability, } \\
\text { Manageabilit } \\
\text { y \& } \\
\text { Adaptability. }\end{array}$} & \multirow{3}{*}{$\begin{array}{l}\text { Affordability and Economic } \\
\text { Performance. }\end{array}$} & Project stakeholder opinion. \\
\hline & & The burden of housing or containment costs \\
\hline & & Price to income ratio. \\
\hline & \multirow{6}{*}{$\begin{array}{l}\text { Manageability aspects of a } \\
\text { building. }\end{array}$} & Stakeholder's opinion. \\
\hline & & The complexity of building design. \\
\hline & & No. of indoor \& outdoor spaces. \\
\hline & & Gross floor area. \\
\hline & & External wall area. \\
\hline & & Area of outdoor spaces. \\
\hline & \multirow[t]{6}{*}{ Adaptability and Flexibility. } & Area of indoor spaces. \\
\hline & & Ease of major changes (Professional opinion). \\
\hline & & Ease of minor changes (Professional opinion). \\
\hline & & No. of rentable zones. \\
\hline & & No. of indoor spaces. \\
\hline & & Stakeholder's opinion. \\
\hline
\end{tabular}

Generally, for three sustainability aspects; indicators, variables, and sub-criteria are numerous and open to be enhanced, i.e., They can be added or deleted ${ }^{10}$. Besides, most of the sustainability assessment systems must be reviewed and checked inside these three aspects. In the following, the weights of indicators and variables can be defined from surveys, the prepared interviews, and methodologies or tools for all aspects of sustainability according to the type of the studied building.

\section{Challenges and Barriers while Applying KPIs for Achieving Sustainability}

From the previous approach to KPIs, their classification, characterization, and measurement units. The challenge is to identify effective indicators that require a clear conceptual basis. So, the study concluded $1,6,7,18,30,47-50$ :

- First, to overcome barriers and challenging aspects of applying and utilize KPIs by: (1) choosing the correct KPIs; (2) reporting KPIs obviously and precisely; (3) gathering data about KPIs; (4) investigating the principal causes of low performance and come up with recommendations; (6) collecting and classifying KPIs under sustainability aspects; (7) easy accessing of data should be comfortable and unrestricted; (8) being costeffective but give value; (9) being quantitative and scientific (quantitative or qualitative standards); (10) being easy to use and general multipurpose quality can be used in many different types of buildings; (11) Allowing partners to compare and contrast different choices; and, (12) making the decisions depends on KPI outcomes.

- Second, to deal with indicators have to: (1) easy to use and a simple and clear interface; (2) support in appraising selection in design decisions; (3) easy utilize by anyone; (4) follow-up periodically; (5) Identify specific issues that may have implications for sustainable buildings for current and future promotions; (6) Continuously check with sustainability aspects; (7) make continuous improvement decision (Resources); and, (8) engage all stakeholders. 


\section{The Relation between KPIs and Sustainability}

In the beginning, an indicator must achieve three main objectives in a project are to increase awareness and understanding of the issues to which it refers; to assist in decision-making; and, to measure the achievement of specific objectives ${ }^{51}$. It is best to think in advance so that aggregated data can be reported to assess sustainability as KPIs ${ }^{52}$. KPIs reflect the goals of any project and provide methods to measure and manage the progress toward these goals as sustainability for additional knowledge and improvement ${ }^{6}$. The indicator method should provide a measure of real performance, a clear description of what can be achieved in terms of future performance objectives, and a benchmark to measure life-cycle progress through sustainability ${ }^{6,50,51}$. KPIs are usually assessed based on the perception of stakeholders who directly influence and are affected by their project $18,19,34$. Thus, it could conclude any of KPIs are considered the most important and functional to include in any study in terms of the sustainability level evaluation of a building ${ }^{23}$. The importance of these means is to help architects, planners, and decision-makers in what is defined as the basics of sustainable design ${ }^{32,41}$. Therefore, KPIs approaches can be employed to identify the level of sustainability of a building or be enhanced.

\section{The Proposed Methodology to Accomplish KPIs of Sustainability Aspects}

The objective of the proposed methodology is to deal with the determination process of the required levels of sustainability; therefore, these levels can be achieved then developed. Because of the multiplicity of approaches in dealing with KPIs; hence, from the previous investigation to KPIs of sustainability and literature review in processing indicators such as application, measurement, evaluation, and improvement. The study can deduce a set of procedures or steps to realize sustainability indicators as a methodology, as shown in Fig. 1. Thus, accomplishing the main objective of needing, accrediting these KPIs, and treating the performance problems to classify these indicators according to the priority for achieving sustainability aspects, then make decisions for developing and optimizing in the form of guiding models.

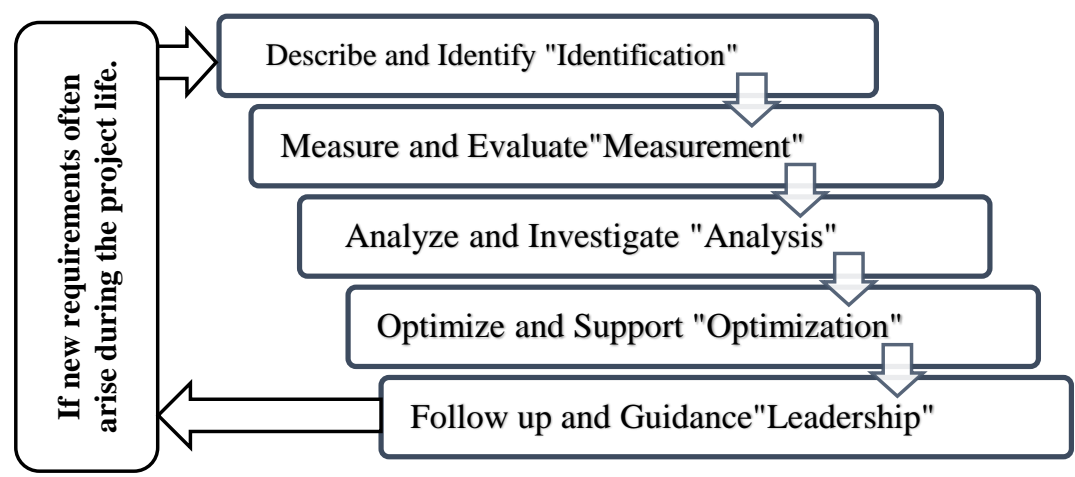

Fig. 1. Demonstrates the stages of the proposed methodology to deal with KPIs of sustainability aspects to accomplish the highest possible levels.

From Fig. 1. The methodology is a cyclic process through the stages systematically occurs throughout the life of a building or a project because of new requirements often arise, as shown in Table 8. 


\begin{tabular}{|c|c|c|c|c|}
\hline & Stage & $\begin{array}{l}\text { Objectives and contents } \\
\text { are to }\end{array}$ & $\begin{array}{c}\text { Support tools and } \\
\text { guidelines }\end{array}$ & $\begin{array}{l}\text { This stage } \\
\text { focuses on }\end{array}$ \\
\hline 泀 & $\begin{array}{l}\text { Describe \& } \\
\text { Identify: } \\
\text { (Identification) }\end{array}$ & $\begin{array}{l}\text { (A) Define and describe the } \\
\text { objectives for sustainability } \\
\text { performance measurement } \\
\text { and improvement; and, (B) } \\
\text { Defining and identify } \\
\text { appropriate and useful } \\
\text { sustainability performance } \\
\text { indicators (KPIs) and } \\
\text { measures for a project. }\end{array}$ & $\begin{array}{l}\text { (A) Criteria, principals, } \\
\text { or factors for selecting } \\
\text { KPIs; (B) Ranking and } \\
\text { categorizing of } \\
\text { sustainability aspects } \\
\text { and specific indicators; } \\
\text { (C) Process maps (input } \\
\text { and output models); and, } \\
\text { Making decisions and } \\
\text { priority through Analytic } \\
\text { Hierarchy Process } \\
\text { (AHP). }\end{array}$ & $\begin{array}{l}\text { "What should be } \\
\text { measured?" } \\
\text { "How should it be } \\
\text { measured?" } \\
\text { "What are suitable } \\
\text { decisions and } \\
\text { more priority? }\end{array}$ \\
\hline 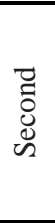 & $\begin{array}{l}\text { Measure \& } \\
\text { Evaluate: } \\
\text { (Measurement) }\end{array}$ & $\begin{array}{l}\text { (A) Carry out and use the } \\
\text { sustainability KPIs and } \\
\text { measures in practices, and, } \\
\text { (B) Measure the } \\
\text { sustainability performance } \\
\text { indicators KPIs of a project. }\end{array}$ & $\begin{array}{l}\text { All instruments, tools, } \\
\text { methods, and } \\
\text { benchmarks, as } \\
\text { mentioned in Table 1-2- } \\
\text { 3-4. }\end{array}$ & $\begin{array}{l}\text { "The efficient and } \\
\text { effective } \\
\text { measurement } \\
\text { system and } \\
\text { methods within a } \\
\text { project." }\end{array}$ \\
\hline 尝 & $\begin{array}{l}\text { Analyze \& } \\
\text { Investigate: } \\
\text { (Analysis) }\end{array}$ & $\begin{array}{l}\text { (A) Analyze the } \\
\text { sustainability KPIs (Cause } \\
\text { and effect) relationships; } \\
\text { and, (B) Determine and } \\
\text { describe enhancement } \\
\text { means and actions to } \\
\text { promote the sustainability } \\
\text { KPIs. }\end{array}$ & $\begin{array}{l}\text { Process maps (input and } \\
\text { output models); } \\
\text { SWOT Analysis; } \\
\text { Keno's Model; and } \\
\text { Cause-Effect Diagram. } \\
\text { E.g., Fishbone. }\end{array}$ & $\begin{array}{l}\text { "How can } \\
\text { sustainability } \\
\text { performance be } \\
\text { enhanced and } \\
\text { promoted?" }\end{array}$ \\
\hline 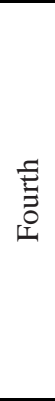 & $\begin{array}{l}\text { Optimize \& } \\
\text { Support: } \\
\text { (Optimization) }\end{array}$ & $\begin{array}{l}\text { (A) Carry out the } \\
\text { improvement means and } \\
\text { actions to achieve the } \\
\text { highest possible levels; (B) } \\
\text { Promote the sustainability } \\
\text { KPIs for development; and, } \\
\text { (C) Enhance and optimize a } \\
\text { building or a project and } \\
\text { their components to realize } \\
\text { sustainability aspects as a } \\
\text { whole. }\end{array}$ & $\begin{array}{l}\text { For designers and } \\
\text { construction managers to } \\
\text { deal with their project or } \\
\text { building to edit, add, or, } \\
\text { delete. }\end{array}$ & $\begin{array}{l}\text { "The } \\
\text { implementation of } \\
\text { the approved and } \\
\text { reported actions } \\
\text { and procedures." } \\
\text { "Doing the best to } \\
\text { improve." }\end{array}$ \\
\hline 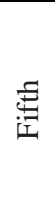 & $\begin{array}{l}\text { Follow up \& } \\
\text { Guidance: } \\
\text { (Leadership) }\end{array}$ & $\begin{array}{l}\text { Stabilize, standardize, and } \\
\text { monitor the developments } \\
\text { and enhanced processes and } \\
\text { improved sustainability } \\
\text { performance KPIs to permit } \\
\text { continuous development. }\end{array}$ & $\begin{array}{l}\text { Follow-up; } \\
\text { Monitoring; and } \\
\text { Post-optimization } \\
\text { evaluation. }\end{array}$ & $\begin{array}{l}\text { "Chances for more } \\
\text { performance } \\
\text { enhancements and } \\
\text { to enable } \\
\text { continuous } \\
\text { development." }\end{array}$ \\
\hline & & & & ntification" to \\
\hline
\end{tabular}

\section{Check the Efficiency, Validity, and Suitability of the Proposed Methodology}

This proposed methodology was introduced in a questionnaire and interviews to the study sample to measure and evaluate the importance of its 
stages and application mechanism suitability and validity for achieving sustainability through the KPIs approach to enhance and optimize its three aspects. If there are other stages, objectives, contents, tools, guidelines; or, what a stage focuses on, as shown in Table 8 that will need to add, edit, delete or, reformulate. Questionnaires and interviews were carried out with experts and practitioners in the fields of sustainability projects such as design, building, and facility management. The number of respondents was seventy persons (twenty-five from architects, fourteen from the academic disciplines, nineteen from the construction management, and twelve from the building consultant) all of them have worked in several projects. They were required to present their judgments about the proposed methodology stages, elements and actions in Table 8. The research used the Likert Scale to assess or rate the importance to each stage, namely: $1=$ Strongly disagree, $2=$ Disagree, $3=$ Undecided, $4=$ Agree and 5= Strongly agree. The questionnaires were analyzed and evaluated by the program (SPSS) to do (One-Sample t-test) (Left-tailed), as in Table 9 to define and rate the importance of the stages and their components, and (two-tailed) to arrange the stages, as in Table 10.

Table 9. Demonstrates the importance rating of the five stages of the proposed methodology based on analyzing the surveys by SPSS.

\begin{tabular}{|c|c|c|c|c|c|c|c|}
\hline \multicolumn{4}{|c|}{ Descriptive Statistics } & \multicolumn{4}{|c|}{ (One-Sample t-test) Left Tailed } \\
\hline \multirow{2}{*}{$\begin{array}{l}\text { The stages of } \\
\text { proposed } \\
\text { methodology }\end{array}$} & \multicolumn{2}{|l|}{ Mean } & \multirow{2}{*}{$\begin{array}{l}\text { Std. } \\
\text { Dev. } \\
\text { Statistic }\end{array}$} & \multirow{2}{*}{$\begin{array}{l}\text { Importance } \\
\text { rating (the } \\
\text { alternative } \\
\text { hypothesis) }\end{array}$} & \multirow{2}{*}{$\begin{array}{l}\mathrm{t}^{*}(\mathrm{p}- \\
\text { value, } \\
\mathrm{n}-1)\end{array}$} & \multirow{2}{*}{$\begin{array}{l}\mathrm{t}(0.05, \\
69)\end{array}$} & \multirow[t]{2}{*}{ Decision } \\
\hline & Statistic & Std. Error & & & & & \\
\hline Identification & 4.900 & 0.036 & 0.302 & 5 & -2.769 & -1.644 & Accepted \\
\hline Measurement & 4.914 & 0.034 & 0.282 & 5 & -2.543 & -1.644 & Accepted \\
\hline Analysis & 4.786 & 0.049 & 0.413 & 5 & -4.338 & -1.644 & Accepted \\
\hline Optimization & 4.929 & 0.031 & 0.259 & 5 & -2.304 & -1.644 & Accepted \\
\hline Leadership & 4.943 & 0.028 & 0.234 & 5 & -2.045 & -1.644 & Accepted \\
\hline $\begin{array}{l}\text { Valid N } \\
\text { (Sample) }\end{array}$ & \multicolumn{3}{|c|}{70 (The number of respondents) } & \multicolumn{4}{|c|}{$\begin{array}{l}\text { Likert Scale to assume the alternative hypothesis } \\
\text { ( } 5=\text { Strongly agree). }\end{array}$} \\
\hline
\end{tabular}

It would be rejected the null hypothesis if the test statistic $\mathrm{t}^{*}$ were greater than $\mathrm{t}$ from right-tailed or smaller than $\mathrm{t}$ from left tailed; accordingly, the alternative hypothesis is accepted.

Table 10. Demonstrates the order of the five stages of the proposed methodology based on analyzing the surveys by SPSS.

\begin{tabular}{|l|l|l|l|l|l|l|l|}
\hline Descriptive Statistics & \multicolumn{4}{l|}{ (One-Sample t-test) Two Tailed } \\
\hline $\begin{array}{l}\text { The stages of } \\
\text { proposed } \\
\text { methodology }\end{array}$ & Mean & $\begin{array}{l}\text { Std. } \\
\text { Dev. }\end{array}$ & $\begin{array}{l}\text { Order of the } \\
\text { stages: the } \\
\text { alternative } \\
\text { hypothesis }\end{array}$ & $\begin{array}{l}\mathrm{t}^{*}(\mathrm{p}- \\
\text { value, } \\
\mathrm{n}-1)\end{array}$ & $\begin{array}{l}\mathrm{t} \\
(0.025, \\
69)\end{array}$ & Decision \\
\cline { 2 - 9 } & Statistic & Std. Error & Statistic & & \\
\hline Identification & 1.057 & .0279 & .233 & 1 & 4.090 & 1.959 & Accepted \\
\hline Measurement & 1.942 & .0279 & .233 & 2 & -4.090 & -1.959 & Accepted \\
\hline Analysis & 3.014 & .0142 & .119 & 3 & 2.000 & 1.959 & Accepted \\
\hline Optimization & 4.085 & .0393 & .329 & 4 & 4.355 & 1.959 & Accepted \\
\hline Leadership & 4.900 & .0361 & .302 & 5 & -5.538 & -1.959 & Accepted \\
\hline
\end{tabular}




\begin{tabular}{|l|l|l|}
\hline $\begin{array}{l}\text { Valid N } \\
\text { (Sample) }\end{array}$ & 70 (The number of respondents) & $\begin{array}{l}\text { P-value for a two-tailed test is always two times } \\
\text { the P-value for either of the one-tailed tests. }\end{array}$ \\
\hline $\begin{array}{l}\text { It would be rejected the null hypothesis if the test statistic } \mathrm{t}^{*} \text { were greater than } \mathrm{t} \text { from right-tailed or smaller } \\
\text { than } \mathrm{t} \text { from left tailed; accordingly, the alternative hypothesis is accepted. }\end{array}$ \\
\hline
\end{tabular}

The survey results confirmed that:

- The methodology could be applied to emerging buildings or existing buildings during the development phase.

- The methodology is a comprehensive and continuous practical approach covering all project stages. It also maintains, takes into account, and controls what was targeted and studied; then improved, developed, and followed-up to preserve the continuity of development throughout the project life.

- All the stages of the deduced and proposed methodology are significant and integrate as well as "Identification stage" is the most important stage to address KPIs. Hence, it must be implemented through a correct procedural manner until it does not negatively affect the results of the other stages.

- The other stages depend on periodic follow-up, analysis, measurement, make decisions, and arrange priority for improvement, promotion, and control and continuous development of what was approved and reported by the first stage.

- Many respondents asked whether new developments or requirements emerge, which will affect the objectives and priorities of making decisions relative to the targeted sustainability levels. Hence, many suggestions were to return to the first stage for adding or modifying inputs again as shown in Fig. 1; accordingly, this methodology was converted to work cyclically.

Consequently, during the first stage of the proposed methodology, the study proposes using Analytic Hierarchy Process (AHP) as a more accurate tool to order the priorities of realizing and accomplishing the three aspects of sustainability and their KPIs, then making decisions; and if needed, using AHP and other tools and guidelines during another four stages of this methodology Table 8. AHP is established to solve complex issues or problems that include multiple criteria and principles and check the consistency ratio to confirm the accuracy of judgments or opinions ${ }^{53-55}$.

\section{The Applied Study of the Proposed Methodology for Achieving Sustainability based on the Approach of KPIs}

After the validation of the proposed methodology has been checked in the above. This section aims to practically apply this methodology into the type of a building such as "a hotel building in the design phase" with focusing on the first stage of this methodology. Through this stage, the study addresses the sustainability KPIs to make decisions and order the priority of applying KPIs of sustainability aspects to accomplish a sustainable project, the stakeholders' requirements, and the objectives of the project throughout its life.

\subsection{Applying the First Stage: The Identification Stage}

Firstly, according to support tools and guidelines as in Table 8, what are:

1. Criteria, principals, or factors for selecting (KPIs):

The criteria were defined and identify by interviews and meetings with the project designer to discuss the design concept and stakeholders to determine their requirements and the project objectives. Moreover, the requirements and standards of the hotel design were studied. Subsequently, AHP is applied to arrange the final considered criteria according to the priority from the viewpoint of the designer and stakeholders and the overall objectives of these types of projects, as shown in Table 11 $27,56-60$. 


\begin{tabular}{|c|c|c|c|}
\hline \multicolumn{2}{|c|}{$\begin{array}{c}\text { The overall objective of the } \\
\text { studied hotel project. }\end{array}$} & \multicolumn{2}{|c|}{$\begin{array}{c}\text { "Access to a sustainable hotel project achieves and supports } \\
\text { sustainability during its life cycle." }\end{array}$} \\
\hline $\begin{array}{c}\text { Priority and } \\
\text { Relative } \\
\text { weight. }\end{array}$ & $\begin{array}{c}\text { The final } \\
\text { considered } \\
\text { criteria. }\end{array}$ & $\begin{array}{l}\text { Relevant } \\
\text { sustainability } \\
\text { aspects. }\end{array}$ & Units \& Measurement. \\
\hline 0.3616 & $\begin{array}{l}\text { Synchronized } \\
\text { quality. }\end{array}$ & $\begin{array}{l}\text { Social- } \\
\text { Environmental- } \\
\text { Economic. }\end{array}$ & $\begin{array}{l}\text { Level of performance to a building; components; } \\
\text { services, systems, and processes; functions; and, } \\
\text { occupants by a survey, tools, and standards. }\end{array}$ \\
\hline 0.2379 & $\begin{array}{c}\text { Energy } \\
\text { management. }\end{array}$ & $\begin{array}{l}\text { Environmental- } \\
\text { Social- } \\
\text { Economic. }\end{array}$ & $\begin{array}{l}\text { All standard units of energy; consumption; and, } \\
\text { energy efficiency retrofit. }\end{array}$ \\
\hline 0.1551 & $\begin{array}{l}\text { Cost control } \\
\text { (adjustment). }\end{array}$ & Economic. & $\mathrm{LCSA}=\mathrm{LCC}+\mathrm{LCA}+\mathrm{SLCA}$ \\
\hline 0.1044 & $\begin{array}{l}\text { Profitability } \\
\text { index. }\end{array}$ & Economic. & $\begin{array}{l}\text { The design is to provide the maximum } \\
\text { contribution to profitability by Affordability, } \\
\text { Manageability, and Adaptability. }\end{array}$ \\
\hline 0.0646 & $\begin{array}{l}\text { Health and } \\
\text { well-being. }\end{array}$ & $\begin{array}{c}\text { Social- } \\
\text { Environmental. }\end{array}$ & $\begin{array}{l}\text { Productivity, Accessibility, Health care, and } \\
\text { Pollution index. }\end{array}$ \\
\hline 0.0344 & Safety. & Social. & $\begin{array}{l}\text { Level of security and applied codes linked to the } \\
\text { safety by a survey, tools, and standards. }\end{array}$ \\
\hline 0.0260 & $\begin{array}{l}\text { Stakeholders' } \\
\text { satisfaction. }\end{array}$ & Social. & Survey-based data; and, Life quality index. \\
\hline 0.0159 & $\begin{array}{c}\text { Innovation and } \\
\text { development. }\end{array}$ & Social. & $\begin{array}{l}\text { Survey-based data; Level of utilizing available and } \\
\text { affordable technology, and techniques; and, Future } \\
\text { of the building. }\end{array}$ \\
\hline
\end{tabular}

2. Ranking and categorizing of sustainability aspects and special indicators;

Secondly, by AHP to be applied to the results of questionnaires and interviews based on the overall objective and final considered criteria as in Table 11.

3. Process maps (input and output models) and making decisions and arranging priority through AHP to answer the questions of this stage are shown in Table 8 to reach a final guiding model.

\subsection{Final Results of the First Stage of the Proposed Methodology}

The final rank and relative weight of the three sustainability aspects; and their KPIs; all of them depended on the priority of application and optimization. This final rank was shown in Table $\mathbf{1 2}$ as a final guiding model according to the priority value and make decisions to achieve the overall objective and final considered criteria regarding the studied hotel project by applying AHP; as shown Table 11. Through the first stage of the proposed methodology, as shown in Table $\mathbf{8}$; to be a sustainable project during its life cycle.

Table 12. Shows the final rank and relative weight of sustainability aspects, and their indicators (KPIs) and variables as a final guiding model. All of them depend on the priority and making decisions regarding the hotel project by AHP to be a sustainable project during its life cycle.

The rank of three aspects of sustainability and the relative weight of each aspect.

\begin{tabular}{|r|l|l|l|}
\hline Aspect & Social & Economic & Environmental \\
\hline $\begin{array}{l}\text { Priority } \\
\text { rank }\end{array}$ & First & Second & Third \\
\hline
\end{tabular}




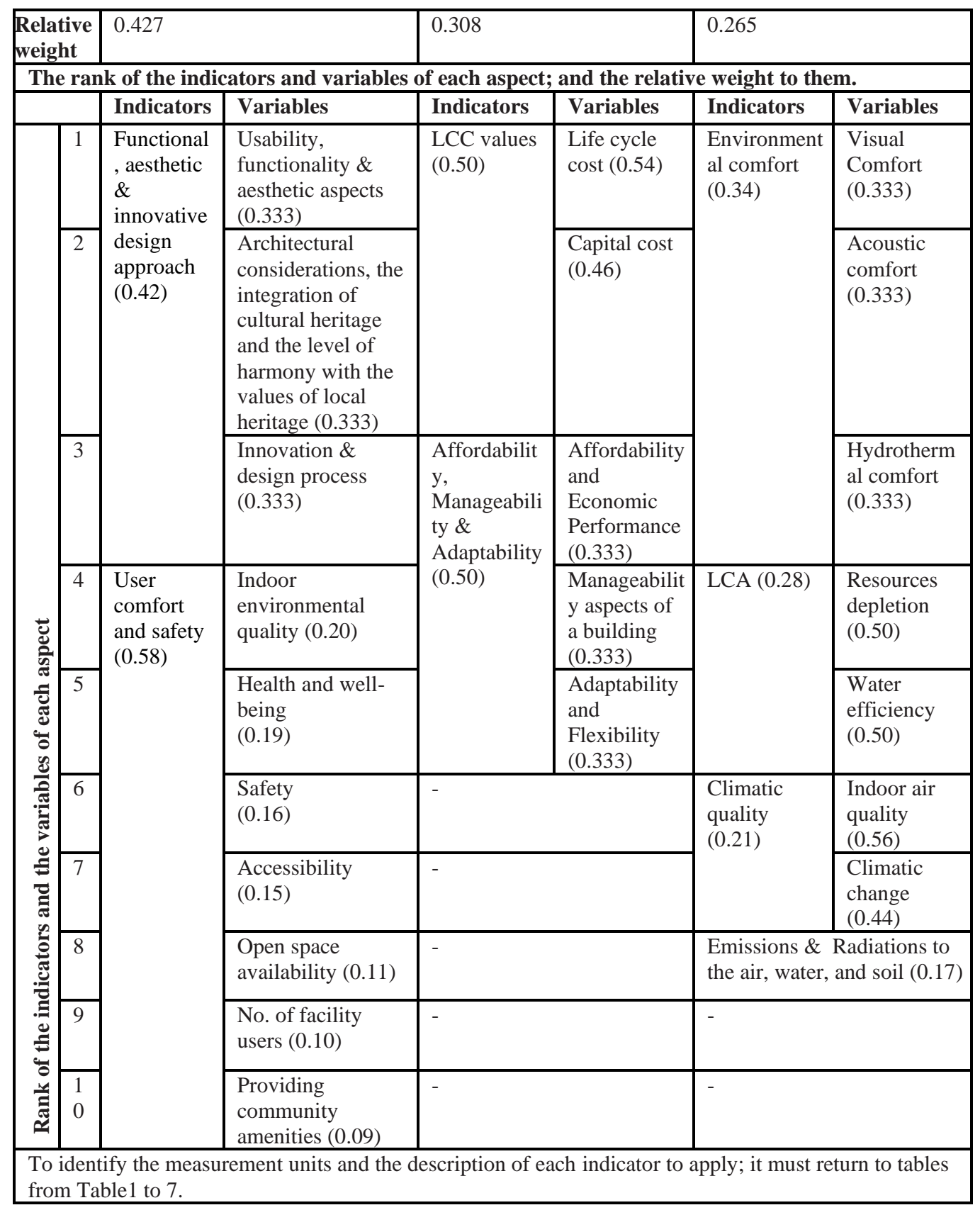




\section{Discussions}

The approach of KPIs is no different from sustainability assessment systems such as LEED or BREEAM but deals with buildings and projects from the perspective of an architect's thought to design and solve problems to achieve quantifiable results. Thus, this approach is a comprehensive approach that includes all tools and means for collecting and analyzing information and global sustainability assessment systems in addressing problems sustainability with its three aspects in the form of indicators . Accordingly, the research tried to bring together different views on sustainability. Are they just systems of evaluation and software; or it is a design thought makes every architect free on how to achieve sustainability through the approach of KPIs?. The three aspects of sustainability are not separate but interdependent and interrelated working together.

The research is a comprehensive perspective of all three sustainability aspects; also, how to deal with them by a method, an approach, or a mechanism to solve the problem of a large number of each aspect indicators and their diversity. Hence, a designer can rank the KPIs of each aspect relative to the importance or priority, make right design decisions, and then proceed to treat and implement gradually in his path toward sustainability.

The research focuses on the initial stage of the proposed methodology as in Fig. 1, because it determines the path of a project and the levels of required sustainability or its maximum possible levels. The rest four stages of the proposed methodology responsible for the measurement, evaluation, analysis, follow-up, optimization, and guidance to what was approved in the first stage; or those stages will work on reformulate the results of the first stage again.

Regarding the practical example of a hotel project, some may agree or disagree with the criteria have been depended on as in Table 11. Nevertheless, it is essential to focus on how to use and employ surveys and AHP in dealing with the design decisions and how to arrange indicators and procedures according to priority to achieve sustainability aspects of sustainable design or improve existing projects.
However, research does not force anyone to use AHP or the used tools and methods during the study in applying the proposed methodology. There are many tools and techniques and other software to make decisions, priorities selection, and preference between alternatives to solutions and proposals.

\section{Conclusions}

The main conclusion is the proposed methodology to treat, realize, and achieve the integrated sustainability within a project by a more precise and effective way that will accomplish the highest possible levels to the sustainability inside various projects and throughout their life permanently for realizing a sustainable project fulfills and promotes all sustainability aspects. This methodology depended on the approach of KPIs and employed AHP in making decisions and ranking the priorities of indicators and procedures in a guiding model to achieve sustainability throughout the project life. The study has deduced and concluded this methodology through previous studies and literature about sustainability and the approach of KPIs, and their methods and mechanisms to achieve the objective of this taken trend.

The study has verified from the validity and efficiency of applying the methodology by presenting it to specialists through surveys; then developing this methodology in the final form. In addition to the practical application of this methodology was conducted on a hotel project as a case study and focusing on the most important stage that is "Identification stage." Besides, AHP and surveys were used to rank priority and make decisions during dealing with KPIs of three sustainability aspects as a final guiding model for being applied, measured, evaluated, and developed inside projects to become an existing sustainable building or a design for another new building.

These depended on the benefiting from the approach of KPIs to examine the concept of the building performance and its correlation with KPIs to collect, classify, and identify the vast majority of KPIs in general; also describe their measurement units and characteristics to overcome barriers and obstacles address the 
concept of sustainability and KPIs of its three aspects in particular. Moreover, this approach identifies and defines the levels of the accomplished and required sustainability and the improvement opportunities next.

All this encourages further research, development, and application of the proposed methodology on other types of buildings. Moreover, profiting from the paper to achieve and promote the sustainability and its aspects in buildings by easy ways in the future, then develop the actual levels of sustainability and follow-up them throughout the project life.

\section{References}

1. Bragança, L., Mateus, R. \& Koukkari, H. Building sustainability assessment. Sustainability 2, 20102023 (2010).

2. Moldan, B., Janoušková, S. \& Hák, T. How to understand and measure environmental sustainability: Indicators and targets. Ecol. Indic. 17, 4-13 (2012).

3. Allacker, K., Trigaux, D. \& De Troyer, F. An approach for handling environmental and economic conflicts in the context of sustainable building. WIT Trans. Ecol. Environ. 181, 79-90 (2014).

4. Malmgren, L. \& Mjörnell, K. Application of a decision support tool in three renovation projects. Sustain. 7, 12521-12538 (2015).

5. Wong, J. K. W. \& Zhou, J. Enhancing environmental sustainability over building life cycles through green BIM: A review. Autom. Constr. 57, 156-165 (2015).

6. Bhuiyan, S. I., Jones, K. \& Wanigarathna, N. an Approach To Sustainable Refurbishment. 31st Annu. ARCOM Conf. 1093-1102 (2015).

7. Kylili, A., Fokaides, P. A. \& Lopez Jimenez, P. A. Key Performance Indicators (KPIs) approach in buildings renovation for the sustainability of the built environment: A review. Renew. Sustain. Energy Rev. 56, 906-915 (2016).

8. Najjar, M., Figueiredo, K., Palumbo, M. \& Haddad, A. Integration of BIM and LCA: Evaluating the environmental impacts of building materials at an early stage of designing a typical office building. $J$. Build. Eng. 14, 115-126 (2017).

9. Chong, H. Y., Lee, C. Y. \& Wang, X. A mixed review of the adoption of Building Information Modelling (BIM) for sustainability. J. Clean. Prod. 142, 4114-4126 (2017).

10. Ahmad, T. \& Thaheem, M. J. Developing a residential building-related social sustainability assessment framework and its implications for BIM. Sustain. Cities Soc. 28, 1-15 (2017).
11. Ahmad, T. \& Thaheem, M. J. Economic sustainability assessment of residential buildings: A dedicated assessment framework and implications for BIM. Sustain. cities Soc. 38, 476-491 (2018).

12. Suzer, O. A comparative review of environmental concern prioritization: LEED vs other major certification systems. J. Environ. Manage. 154, 266-283 (2015).

13. Wu, P., Song, Y., Hu, X. \& Wang, X. A preliminary investigation of the transition from green building to green community: Insights from LEED ND. Sustain. 10, 1-14 (2018).

14. Wu, W. \& Luo, Y. Investigating the Synergies of Sustainability and BIM through Collaborative Project-based Learning. Proc. ASEE Annu. Conf. Expo. 26.1043.1-13 (2015).

15. Doan, D. T. et al. A critical comparison of green building rating systems. Building and Environment 123, 243-260 (2017).

16. Nilashi, M. et al. A knowledge-based expert system for assessing the performance level of green buildings. Knowledge-Based Syst. 86, 194-209 (2015).

17. Ibem, E. O., Opoko, A. P., Adeboye, A. B. \& Amole, D. Performance evaluation of residential buildings in public housing estates in Ogun State, Nigeria: Users' satisfaction perspective. Front. Archit. Res. 2, 178-190 (2013).

18. Yahya, M. \& Ibrahim, M. Building Maintenance Archievement in High Rise Commercial Building. Int. J. Sustain. Dev. 04, 39-46 (2012).

19. Li, Y., O’Donnell, J., García-Castro, R. \& VegaSánchez, S. Identifying stakeholders and key performance indicators for district and building energy performance analysis. Energy Build. 155, 115 (2017).

20. Douglas, J. Facilities Building performance and its relevance to facilities management. Facilities 14, 23-32 (1996).

21. Khair, N., Ali, H. M., Sipan, I., Juhari, N. H. \& Daud, S. Z. Post occupancy evaluation of physical environment in public low-cost housing. J. Teknol. 75, 155-162 (2015).

22. Tookaloo, A. \& Smith, R. Post occupancy evaluation in higher education. Procedia Eng. 118, 515-521 (2015).

23. Montarroyos, D. C. G., de Alvarez, C. E. \& Bragança, L. Methodology for environmental assessment in Antarctic buildings. Environ. Impact Assess. Rev. 73, 104-113 (2018).

24. Mohammed, A. B. Developing Post-Occupancy Evaluation using Value Engineering in the Higher Education Buildings. Int. J. Eng. Res. Technol. 7, 67-78 (2018).

25. González-Gil, A., Palacin, R. \& Batty, P. Optimal 
energy management of urban rail systems: Key performance indicators. Energy Convers. Manag. 90, 282-291 (2015).

26. El-feki, S. M. T. \& Saleh, M. S. Journal of Engineering Sciences Faculty of Engineering POST-OCCUPANCY EVALUATION STUDY OF A UNIVERSITY PREMISES IN CAIRO, EGYPT. 46, 599-616 (2018).

27. Ingram, H. What is ' good', hotel design? Josef Ransley and. 19, 79-86 (2001).

28. Barlish, K. \& Sullivan, K. How to measure the benefits of BIM - A case study approach. Autom. Constr. 24, 149-159 (2012).

29. Aziz, N. D., Nawawi, A. H. \& Ariff, N. R. M. ICT Evolution in Facilities Management (FM): Building Information Modelling (BIM) as the Latest Technology. Procedia - Soc. Behav. Sci. 234, 363371 (2016).

30. Mateus, R. \& Bragança, L. Sustainability assessment and rating of buildings: Developing the methodology SBToolPT-H. Build. Environ. 46, 1962-1971 (2011).

31. Lavy, S., Garcia, J. A. \& Dixit, M. K. Establishment of KPIs for facility performance measurement: Review of literature. Facilities 28, 440-464 (2010).

32. ALwaer, H. \& Clements-Croome, D. J. Key performance indicators (KPIs) and priority setting in using the multi-attribute approach for assessing sustainable intelligent buildings. Build. Environ. 45, 799-807 (2010).

33. Meier, H., Lagemann, H., Morlock, F. \& Rathmann, C. Key performance indicators for assessing the planning and delivery of industrial services. Procedia CIRP 11, 99-104 (2013).

34. Ugwu, O. O. \& Haupt, T. C. Key performance indicators and assessment methods for infrastructure sustainability-a South African construction industry perspective. Build. Environ. 42, 665-680 (2007).

35. Parmenter, D. Key performance indicators: developing, implementing, and using winning KPIs. (John Wiley \& Sons, 2015). doi:10.1002/9781119019855

36. Hooper, P., Knuiman, M., Foster, S. \& Giles-Corti, B. The building blocks of a 'Liveable Neighbourhood': Identifying the key performance indicators for walking of an operational planning policy in Perth, Western Australia. Heal. Place 36, 173-183 (2015).

37. Lavy, S. A Literature Review on Measuring Building Performance by Using Key Performance Indicators. Environ. Eng. In AEI 201, 369-377 (2011).

38. Lavy, S., Garcia, J. A. \& Dixit, M. K. KPIs for facility's performance assessment, Part II:
Identification of variables and deriving expressions for core indicators. Facilities 32, 256-274 (2014).

39. Zuo, J. \& Zhao, Z. Y. Green building researchcurrent status and future agenda: A review. Renewable and Sustainable Energy Reviews 30, 271-281 (2014).

40. Lai, J. H. K. \& Yik, F. W. H. Perception of importance and performance of the indoor environmental quality of high-rise residential buildings. Build. Environ. 44, 352-360 (2009).

41. Shoubi, M. V., Shoubi, M. V., Bagchi, A. \& Barough, A. S. Reducing the operational energy demand in buildings using building information modeling tools and sustainability approaches. Ain Shams Eng. J. 6, 41-55 (2014).

42. Lützkendorf, T. Assessing the environmental performance of buildings: trends, lessons and tensions. Build. Res. Inf. 46, 594-614 (2018).

43. Kamali, M., Hewage, K. \& Milani, A. S. Life cycle sustainability performance assessment framework for residential modular buildings: Aggregated sustainability indices. Build. Environ. 138, 21-41 (2018).

44. Almahmoud, E. S. \& Doloi, H. K. Social Sustainability Health Check: a Model for Integrating Stakeholders ' Interests in Evaluating and Optimising Social Sustainability Performance of Construction Projects. CIB Int. Conf. 2012, 98105 (2012).

45. Finkbeiner, M., Schau, E. M., Lehmann, A. \& Traverso, M. Towards life cycle sustainability assessment. Sustainability 2, 3309-3322 (2010).

46. Bieler, A. \& McKenzie, M. Strategic planning for sustainability in Canadian higher education. Sustain. 9, 161 (2017).

47. Al-Jebouri, M. F. A., Saleh, M. S., Raman, S. N., Rahmat, R. A. A. B. O. K. \& Shaaban, A. K. Toward a national sustainable building assessment system in Oman: Assessment categories and their performance indicators. Sustain. Cities Soc. 31, 122-135 (2017).

48. Scheer, A. W., Jost, W., He, H. \& Kronz, A. Corporate performance management: ARIS in practice. Corporate Performance Management: ARIS in Practice (Springer, 2006). doi:10.1007/3540-30787-7

49. Vaughter, P., McKenzie, M., Lidstone, L. \& Wright, T. Campus sustainability governance in Canada: A content analysis of post-secondary institutions' sustainability policies. Int. J. Sustain. High. Educ. 17, 16-39 (2016).

50. Das, P. \& Chandra, T. S. Sustainability Through Energy Efficient Building. 8, 198-203 (2019).

51. Heilala, V. T. T. J. et al. The concept for sustainability performance indicators, reporting and 
improvement. 30, 1-48 (47) (2015).

52. Perrini, F. \& Tencati, A. Sustainability and Stakeholder Management: the Need for New Corporate Performance Evaluation and Reporting Systems. 308, 296-308 (2006).

53. Saaty, T. \& Vargas, L. Models, methods, concepts $\&$ applications of the analytic hierarchy process. Driven Demand Oper. Manag. Model. 175, 1-20 (2012).

54. Goepel, K. D. Implementing the Analytic Hierarchy Process as a Standard Method for Multi-Criteria Decision Making in Corporate Enterprises - a New AHP Excel Template with Multiple Inputs. Proc. Int. Symp. Anal. hierarchy Process 2013, 1-10 (2013).

55. Kwok, W., Johnny, W., Ã, J. K. W. W. \& Li, H. Application of the analytic hierarchy process ( AHP ) in multi-criteria analysis of the selection of intelligent building systems Application of the analytic hierarchy process ( AHP) in multi-criteria analysis of the selection of intelligent building sys. 43, 108-125 (2014).

56. Xu, P. P., Chan, E. H. W. \& Qian, Q. K. Key performance indicators (KPI) for the sustainability of building energy efficiency retrofit (BEER) in hotel buildings in China. Facilities 30, 432-448 (2012).

57. Shirley Kuo, Clarissa Nathania, Ai-Lin Wang, WeiLing Chen \& Bee Mon Yap. Study on the Experimental Marketing and Customer Intention of Design Hotel. J. Tour. Hosp. Manag. 6, 304-317 (2019).

58. Tuominen, P. P. \& Ascenção, M. P. The hotel of tomorrow: A service design approach. J. Vacat. Mark. 22, 279-292 (2016).

59. Chung, G. \& Chung, D. WOW the Hospitality Customers: Transforming Innovation into Performance Through Design Thinking and Human Performance Technology. Perform. Improv. 57, 14 25 (2018).

60. Kirillova, K., Chan, J., Kirillova, K. \& Chan, J. “ What is beautiful we book": hotel visual appeal and expected service quality. Int. J. Contemp. Hosp. Manag. 30, 1788-1807 (2018). 
تحقيق جوانب الاستدامة بالاعتماد على مدخل مؤشرات الأداء الرئيسية خلال حياة المباني المستجدة

عبد الله بدوي محمد جودة

مدرس بقسم الهندسة المعمارية- كلية الهندسة- جامعة الفيوم

الملخص

يسعى البحث نحو تحقيق الاستدامة الثاملة للوصول إلى تصميم مستدام خلال مراحل حياة المبني، ويأخذ في الاعتبار ويراعي ويعالج مشكلة تعدد الاتجاهات والأساليب لتحقيق الاستدامة وجميع جوانبها (البيئية- الاجتماعية- الاقتصادية). وبسبب الاتجاه العام نحو جعل هذه الجوانب كمؤشرات، اعتمد البحث على مدخل مؤشرات الأداء الرئيسية (KPIs) كمدخل ناجح لتعزيز جوانب

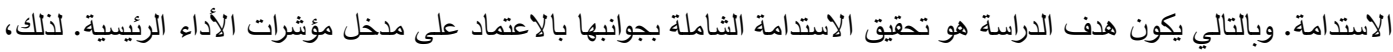
تتاولت الدراسة هذا المدخل ودوره القيم والفعال في حل مشاكل الأداء للمشروعات وتطويره أيضاً. ثم جمع وتصنيف مؤشرات الأداء الرئيسية لكل جانب من جوانب الاستدامة الثلاثة. ودراسة وتحليل تحديات تطبيق واستخدام مؤشرات الأداء الرئيسية، وعلاقتها

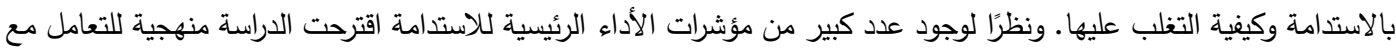
مؤشرات الأداء الرئيسية لكي يمكن تصنيف الجوانب الثلاثة للاستدامة ومؤشرات الأداء الرئيسية الخاصة بهج وفقًا لأولوية التطبيق والتتفيذ والأهمية تبعاً لطبيعة وأهداف المشروع محل الدراسة ولتساعد في اتخاذ القرارات لتحقيق أعلى مستويات الاستدامة الممكنة طوال حياة المشروع أو المبني. تم تقييم صلاحية هذه المنهجية المقترحة من خلال الدراسات الاستقصائية مثل الاستبيانات واللقاءات الثخصية. وتطبيق هذه المنهجية على نوع من المشروعات مثل مشروع فندق في مرحلة التصميم، والحصول على النتائج في صورة نموذج إرشادي نهائي بعد إجراء المرحلة الاولي (مرحلة الوصف والتحديد) من المنهية المقترحة، والذي يمكن قياسه وتقييمه وتطويره ومتابعته من خلال باقي مراحل المنهجية المقترحة (أربعة مراحل) أثناء تطبيق هذا النموذج الإرشادي في كل مراحل حياة المشروع ليكون مشروعًا مستدامًا.

الكلمات الرئيسية: مؤشرات الأداء الرئيسية (KPIs) - جوانب الاستدامة (الاقتصادية- الاجتماعي- البيئية) - فندق -نموذج إرشادي نهائي - عملية التحليل الهرمي (AHP). 